\title{
Halophytes of Tersko-kumsk Lowland Area, Their Protection and Rational Use
}

\author{
A S Abdurzakova1, M A-M Astamirova², R S Magomadova1, S A Israilova1, \\ Kh R Khanaeva', B A Khasueva', A M Umaeva ${ }^{3}$, and Z I Shakhgirieva ${ }^{3}$ \\ ${ }^{1}$ Faculty of Natural Sciences, Chechen State Pedagogical University, Grozny, Russia \\ ${ }^{2}$ Academy of Sciences of the Chechen Republic, Department of Biological and Medical research, \\ Faculty of Natural Sciences, Chechen State Pedagogical University, Grozny, Russia \\ ${ }^{3}$ Faculty of Biology, Chechen State University, Grozny, Russia
}

\section{Abstract}

Article provides a brief analytical review of studies of halophilic flora species of TerskoKumsk lowland area. The most important representatives are indicated, the adaptive properties of different halophyte groups are considered. Their resource value is noted (fodder, medicinal, melliferous, tannic, etc.). In the systematic aspect, the halophilic flora exhibits Mediterranean features, dicotyledons dominate in it, club-moss and horsetails are completely absent, ferns are minimally present. In the edaphic relation, most

Corresponding Author:

A S Abdurzakova

anna-grozny@mail.ru

Received: 25 October 2019

Accepted: 15 November 2019

Published: 25 November 2019

Publishing services provided by Knowledge E

(c) A S Abdurzakova et al. This article is distributed under the terms of the Creative Commons Attribution License, which permits unrestricted use and redistribution provided that the original author and source are credited.

Selection and Peer-review under the responsibility of the AgroSMART 2019 Conference Committee.

\section{G OPEN ACCESS} species of halophytes are obligate, confined to one type of substrate, and the vast majority of halophytes are confined to the steppe belt, the subalpine belt, the belt of upland xerophytes and the alpine belt are in descending order, least of all halophytes in the forest belt, individual species live in subnival belt. The question of the protection of solonchak vegetation and solonchak steppes as a peculiar ecosystems, with a distinctive landscape and original flora containing a highly specialized ecological group of plants, which testifies to the relationship of the nature of plants with the environment. Halophilic cenoses can serve as indicators of the soil, chemical composition and depth of groundwater.

Keywords: Tersko-Kumsk lowland, halophytes, main groups, characteristic types, distribution, resource value, protection, rational use.

\section{Introduction}

The flora study of Tersko-Kumsk lowland from different points of view was done by S.G. Gmelin, F. Marshall-Bibershtein, Kh. Steven, C.A. Meyer [1--5] and later researchers [6--10].

On the territory of the Tersko-Kumsk lowland, against the general background of semi-desert and desert, there is vegetation of steppes, sands, solonchaks, and meadows and in some places mesophytes. Lowland vegetation is rather uniform, scrubby, sparse and does not form a continuous cover. The overwhelming majority of plants in 
the summer ceases to develop, burns out, and the lowland acquires a uniform yellowishgray color. Only in spring and autumn, due to less high temperatures and high humidity, the surface is covered with a green cover of plants. Ephemera and ephemeroids are widely represented, among which Poa bulbosa L. stands out with its bright green color. However, the general background of the area is created by wormwood, especially the Tauride (Artemisia taurica Willd.), various saltwort (Salsola crassa Bieb., S. dendroides Pall., S. laricina Pall.) and others.

The nature of the vegetation distribution of the Tersko-Kumsk lowland, depending on the differences in vegetation, natural areas that contrast with each other are clearly distinguished, claiming the rank of individual botanical and geographical areas: Nogai desert-steppe, Kumsko-Caspian solonchak-desert, the Terek Delta with azonal floodplained meadows, shrubs, forests and fluxes.

\section{Methods and Materials}

The research object is the flora of Tersko-Kumsk lowland area. The material for writing the article was the herbarium collections gathered in the course of expeditionary research by members of the Academy of Sciences of the Chechen Republic. A total of about 500 herbarium leaves of plants were collected, determined and mounted. In addition, herbarium specimens from $\mathrm{CI}$ RAS and ChGPU funds, collected in the study area in different years, were processed.

Taxonomic identification of the collected plants was carried out according to the 3 volumes of "Flora of the North Caucasus" by A.I. Galushko [11] and "Determinant of Caucasian plants" by A.A. Grossgeim [12]. The definition correctness was checked by comparison with morphological description of "Flora of the USSR" [13] and "Flora of the Caucasus" by A.A. Grossgeim [14], and for species not included in these reports according to the diagnoses in the original sources. In addition to these publications, a summary of S.K. Cherepanov was used to clarify the types [15].

\section{Results}

The composition and structure of plant communities are determined by the specific environmental conditions prevailing in the course of historical development of TerskoKumsk lowland area, which is quite rich in various plant habitats. There are broadleaved forests, saline, sandy, clayey areas, fragments of steppes and semi-deserts, wetlands and weedy habitats. The differences between these types of habitats relate to many 
parameters of the environment, ranging from moisture to the physical and chemical characteristics of the soil. Within the study area, we include the following typical habitats: sandy desert, sea shores, solonchaks, clay and sandy semi-deserts, steppes, river banks and coastal meadows, fluxes and marshes, freshwater bodies, forests, arable lands, weedy places.

Halophytes, representing a highly specialized ecological group, indicate a relationship between the nature of plants and the environment, and their cenoses are indicators of the soil, chemical composition and depth of groundwater [16--18].

Halophytes are plants that can tolerate or withstand soil salinity. Depending on the excess of salt solutions in the soil, they are divided into halophytes and glycophytes.

The great Russian scientist A.A. Shakhov [19] gives the following ecological and biological formulation of the concept "halophyte": "Halophytes are plants of saline habitats that are adapted to the high content of solonchak salts in the soil, due to hereditary properties that have arisen in the process of historical development and are formed in individual development".

According to A.A. Shakhov [19], the adaptation of plants to the conditions of salinization is carried out through salt accumulation, salt excretion and salt resistance. According to these characteristics, halophytes are divided into three ecological and physiological groups: salt-accumulating, salt-releasing and salt-impermeable.

Salt-accumulating halophytes (euhalophytes) are plants that grow well and develop normally only when there is a required amount of chlorides and sulfates, which they accumulate in large quantities in their bodies and because of their hereditary needs for soil salinization. This group of halophytes is characterized by a salt effect (Salicornia europaea L., Suaeda confusa (L.) Pall., Su. altissima (L.) Pall., Salsola soda L., Spergularia maritima (L.) C. Presl, S. marina (L.) Griseb., Bassia sedoides (Pall.) Freitag \& G. Kadereit and etc.).

Salt-releasing halophytes (crinohalophytes) are plants with a lower hereditary need for salts. Possessing the ability to absorb a lot of salts, they can release some of the salts, "filtering" them through themselves on the surface of their organs. These include: Limonium meyeri (Pall. ex Willd.) Stank. , L. caspium (Willd.) Gams, Aeluropus littoralis (Gouan) Parl., Crypsis alopecuroides (Piller \& Mitterp.) Schrad., Psylliostachys spicata (Willd.) Nevski , Tamarix gracilis Willd., T. ramosissima Ledeb. and etc.

Salt-impermeable (saltproof) halophytes are plants with a low hereditary need for salts. They develop well without salinization and they have very limited plasma saline impenetrability on saline soils, owing to this, protect themselves from excess salt. This group of halophytes includes: Plantago maritima L., Tripolium pannonicum ( Jacq.) 
Dobrocz., Artemisia taurica Willd., A., maritima L., Juncus gerardii Loisel., Carex distans L., Leymus racemosus (Lam.) Tzvelev., Puccinellia poecilantha (K. Koch.) Gross, P. distans (Jacq.) Parl. and etc.

In contrast to salt-accumulating, salt-releasing and salt-impermeable, the halophytes do not have a clearly pronounced salt effect.

At last, there is another group of highly salt-resistant halophytes (Juncus gerardii Loisel., J. maritimus Lam. и др.), in which salt removal occurs by dropping parts of plants. Older leaves with a high salt substance dry up and are dropped, and meanwhile growing young ones are capable of absorbing salt. This is characteristic of such halophilic rosette plants as Plantago maritima L., Triglochin maritimum L., Aster tripolium L. and etc. Absolutely the same function is performed by the utricular (bubble-shaped) hairs of the epidermis of some species of Atriplex and Halimione. They accumulate salts in the cell sap, and soon die off and are replaced by new ones.

Communities with halophytic vegetation are used extremely insufficiently, only 15--20 $\%$ of these lands are involved in agricultural use. At the same time, the natural phytocenoses of solonchaks are raw materials source for forage plants (Festuca orientalis (Hack.) V. Krecz. \& Bobr., Elytrigia elongata (Host) Nevski, Puccinellia gigantea, Melilotus officinalis. Galega orientalis, Trifolium fragiferum, Medicago lupulina, Lotus tenuis and etc.), medical (Artemisia taurica, contains lactones tauricin, tauremizin, essential oil; Melilotuso fficinalis, M. dentatus, M. albus -- coumarins, glycosides, carotene; Limonium meyeri -- tannins; Gypsophila trichotoma -- saponins; Iris halophila -- glycosides, vitamin "C", essential oil; Salsola soda, S. tragus -- alkaloids of salsolin and salsolidine, etc.), melliferous (Goniolimon tataricum, Limonium caspium, L. meyeri, Grambe steveniana, Tamarix gracilis, Melilotus officinalis, Galega orientalis, Glycyrrhiza glabra and etc.), phytomeliorative (Tamarix gracilis, T. ramosissima, T. laxa, Leymus sabulosus, Galega orientalis, Gypsophila trichotoma, Melilotus officinalis and etc.), wood-pulp and paper (Phragmites australis, Elytrigia elongata, Bolboschoenus maritimus, Scirpus litoralis) and a number of other useful plants [20] (Gubanov, and etc., 1976).

Separate halophytes (Elytrigia elongata, E. repens) serve as valuable plant breeding material [21--26]. Allocation of a part of saline lands as reserves should not contradict the possibility of their practical use. Usually, the use of saline lands is accompanied by the implementation of such activities as drainage, washing, irrigation, application of mineral and organic fertilizers and others that are associated with a direct impact on the soil. There is another way to develop and increase the productivity of saline lands -- the widespread cultivation of halophyte plants on them, which form the natural cover of solonchaks, salt marshes and solods. 
Here, in a broad sense, experiments can be made to create multi-tiered pastures, to increase the biological productivity of phytocenosisby introducing plant species in their composition, having a relatively high yield of vegetative mass and the ability to adapt to the conditions of salinization. The most promising in this respect are primarily wild-growing salt-resistant cereals: Puccinellia gigantea, P. distans, P. poecilantha, $P$. dolicholepis and their interspecific hybrids Puccinellia gigantea $\times P$. poecilantha, P. gigantea x P. distans. Festuca orientalis, Elytrigia elongata, Cynodon dactylon, Alopecurus arundinaceus and etc. Adding to them such a cultivated plant as Slavic alfalfa local, very salt-resistant variety, will significantly improve the quality of grass stand. Melilotus albus, M. officinalis, M. dentatus. Galega orientalis and etc. can be used among wild salt-resistant representatives in this regard -- herbs with rather valuable fodder values, resistant to overwetting of solonchak and saline places. In the wild, their yield reaches 15--20 centners/ha of hay; sweet clovers are especially good for silage, as they contain a lot of digestible protein.

The communities of euhalophytes are used as poor quality pastures, their forage value increases with the presence of cereals in them. At the same time, the clean thickets of Salicornia europaea and Salsola soda are good year-round fattening feeds for cattle, horses and sheep. Community productivity reaches 30 centners/ha of green mass. A promising species, giving a large green biomass (up to 70 centners/ha), but requiring a detailed study of the biochemical composition, is sea rocket (Cakile euxina) -- psammohalophyte dominating in the vegetation cover of saline sandy places [24].

Over moistened saline lands should be subjected to partial drainage, and their vegetation cover -- to milling. Such agrotechnical methods allow achieving good development, seeding and high yield of many salt-resistant cereals, especially saltmarshgrass, which have a high substance of digestible protein [26]. The economic value of saltmarsh-grass is much higher than euhalophytes. Saltmarsh-grasses give early nutritious food, rich in minerals; the height of the grass stand reaches $80--85 \mathrm{~cm}$, the yield is up to 10 centners/ha of hay. In a number of areas of the Tersko-Kumsk lowland areas, saltmarsh-grass communities are successfully used for hay harvesting in the saline massifs. Mowing and grazing of communities is advisable to carry out until the end of their flowering, when the productivity and palatability of the saltmarsh-grasses, due to their low lignification, are the highest [26--30].

Wheat grass (46,0 centner/ha of green mass), shoreweed saltmarsh-grasses (27,0 centner/ha), gonimic saltmarsh-grasses (18,0 centner/ha) and other communities giving early nutritious food, rich in mineral substances, are valuable. 
Solonchak vegetation and solonchak steppes are decreasing every year. It is necessary to take measures to preserve them as a kind of ecosystem that characterizes the distinctive landscape of certain regions of the North Caucasus. The preservation of solonchak vegetation has an important cognitive significance because halophytes representing a highly specialized ecological group indicate a relationship between the nature of plants and the environment, and their cenoses are indicators of soil, chemical composition and depth of groundwater [17].

The optimal use of saline land resources requires a comparison of costs and the resulting products. In certain areas of the Tersko-Kumsk lowland, it would be rational to use saline land and solonchak vegetation than to meliorate introduce them into crop rotation, and then maintain productivity at the expense of high costs and effort. On saline lands, the creation of multi-tiered pastures consisting of halophilic shrubs would be an economically viable and promising step (Halocnemum strobilaceum, Aellina glauca, Tamarix gracilis, T. laxa, T. ramosissima, T. meyeri. Nitrarla schoberi), semi-shrubs (Camphorosma monspeliacum, Kochia prostrata, Halimione verrucifera, Frankenia hirsuta. Artemisia tschernieviana, A. procera), as well as perennial and annual grasses. The multi-layered location of aboveground and underground organs, on the one hand, will enhance bio-productivity and, on the other, improve the resistance of plant communities of saline lands [26--30].

There are agrocenoses occupied by rice culture, in connection with which the soil salinity is progressing and becoming irreversible on the territory of Tersko-Kumsk lowland. There are areas of natural solonchak and saline vegetation that are strongly reduced under the influence of man and under the influence of overgrazing, transforming into low productive groups.

Today, extremely rare species in the halophilic cover of the saline lands of the North Caucasus are Puccinellia fominii, P. sclerodes, Iris halophila, Frankenia hirsuta and some others; endangered communities are from Halocnemum strobilaceum, Elytrigia elongata, Triglochin maritima.

We offer to add some rare and endangered species of flora families of the studied territory to the Red Book of the North Caucasus: Poaceae -- Puccinellia fominii Bilyk., P. sclerodes V. Kxecz., P. dolicholepis V. Krecz., Elytrigia elongata (Host.) Nevski; Frankeniaceae -- Frankenia hirsuta L.; Iridaceae -- Iris halophila Pall.; Chenopodiaceae -- Halocnemum strobilaceum (Pall.) Bieb.; Papaveraceae -- Glaucium flavum Crantz; Juncaginaceae -- Triglochin maritimum L. 


\section{Conclusion}

There is a need to create custom territories for the protection of virgin solonchak vegetation in the vicinity of Kissyk Lake and Steppe Pearl Lake, represented by unique areas of solonchak steppes.

It is currently impossible to find ways of economically reasonable management without ecological ways, which determine the state of the biosphere of Earth as a whole. A well-considered, environmentally justified intervention in the historically established ecosystem of solonchaks will allow on the one hand, preserving an interesting phenomenon of nature, and on the other, involving wasted saline lands of the North Caucasus in the economic circulation. The task of the near future is to create highly productive forage agrocenoses on saline lands. The latter is impossible without preserving and comprehensively studying the halophilic flora, its communities, taking into account the ecological, physiological and anatomical features of the species forming it.

\section{References}

[1] Gmelinm, S.G. (1784). Reise durch Russ/and zur Untersuchung der drei Natur-Reiche. Theil IV. St. Petersbourg, $304 \mathrm{p}$.

[2] Bieberstein, F.M., Marschall, F.A. (1800). Beschreinbung der Lander zwischen den Flussen Terek und Kur am Kaspischen Meere. Frankfurt a/M., 211 p.

[3] Bieberstein, F.M. (1808--1819). Flora Taurico-Caucasica exhibits stripes phaenogamas in Chersoneso Taurica et regionibus Caucasicis sponte crescentes. Charcoviae,: vol. 1, 428 p., 1808; vol. 2, 447 p., 1808; vol. 3, 654 p., 1819.

[4] Steven, Ch. (1812). Cataloque des plantes rares on nouvelles, observant pendant voyage autor du Caucase oriental. Mem. d. I. Soc. Imp., no. 3, pp. 244--270.

[5] Meyer, C.A. (1831). Verzeichniss der Pflanzen welche wahrend der auf. All erhochsten Befehl in den Jahren 1829 und 1830 uninterommenen Uss des Caspischen Meers ge fungen und eingesammelt worden sind. St. Peterburg, $241 \mathrm{p}$.

[6] Galushko, A.I. (1975). Vegetative cover of Chechen-Ingushetia. Grozny: ChechenIngush. Prince publishing house, p. 5--32.

[7] Prima, V.M. (1974). To the flora of the tract Kissyk (Eastern Ciscaucasia). Flora and vegetation of the Eastern Caucasus: Coll. articles teaching. Ordzhonikidze: Department of Botany Chech.-Ingush, state. pedagogical Inst., pp. 85--98.

[8] Abdurzakova, A.S. (2008). Ecological-biological and phytocenological analysis of the flora of the Terek-Kuma lowland. Master's dissertation. Makhachkala, 28 p. 
[9] Omarkhadzhieva, F.S. (2011). Flora of the Chechen Republic and its analysis. Thesis for the degree of candidate of biological sciences. Astrakhan, $144 \mathrm{p}$.

[10] Umarov, M.U., Taysumov, M.A. (2011). Abstract of the flora of the Chechen Republic. Grozny, p. 152.

[11] Taysumov, M.A., Magomadova, R.S. (2016). Analysis of the vegetation cover of the Kissyk tract of the Shelkovsky district of the Chechen Republic. News of the DSPU, no. 1, pp. 34--41.

[12] Galushko, A.I. (1978--1980). Flora of the North Caucasus. Rostov: Rostov State University, vol. 1, 1978, 317 p.; vol. 2, 1980, 350 p.; vol. 3, 1980, 327 p.

[13] Grossheim A.A. (1949). Determinant of Caucasian plants. Moscow, 747 p.

[14] Flora of the USSR, 1934--1964, vol. I--XXX: vol. I. Leningrad, 1933, 302 p.; vol. II. Leningrad, 1934, 778 p.; vol. III. Leningrad, 1935, 636 p.; vol. IV. Leningrad, 1935, 760 p.; vol. V. Moscow; Leningrad, 1936, 762 p.; vol. VI. Moscow; Leningrad, 1936, 956 p; vol. VII. Moscow; Leningrad, 1937, 790 p.; vol. VIII. Moscow; Leningrad, 1939, 692 p.; vol. IX. Moscow; Leningrad, 1939, 546 p.; vol. X. Moscow; Leningrad, 673 p.; vol. XI. Moscow; Leningrad, 1945, 432 p.; vol. XII. Moscow; Leningrad, 1946, 919 p.; vol. XIII. Moscow; Leningrad, 1948, 588 p.; vol. XIV. Moscow; Leningrad, 1949, 790 p.; vol. XV. Moscow; Leningrad, 1949, 743 p.; vol. XVI. Moscow; Leningrad, 1950, 648 p.; vol. XVII. Moscow; Leningrad, 1951, 390 p.; vol. XVII. Moscow; Leningrad,1952, 803 p.; vol. XIX. Moscow; Leningrad, 1953, 753 p.; vol. X. Moscow; Leningrad, 1954, 556 p.; vol. XXI. Moscow; Leningrad, 1954, 704 p.; vol. XXII. Moscow; Leningrad,1955, 862 p.; vol. XXIII. Moscow; Leningrad,1958, 776 p.; vol. XXIV. Moscow; Leningrad, 1957, 502 p.; vol. XXV. Moscow; Leningrad, 1959, 630 p.; vol. XXVI. Moscow; Leningrad, 1961, 939 p.; vol. XXVII. Moscow; Leningrad, 1962, 758 p.; vol. XXVIII. Moscow; Leningrad, 1963, 654 p.; vol. XXIX. Moscow; Leningrad, 1964, 798 p.; vol. XXX. Moscow; Leningrad,1964, $732 \mathrm{p}$.

[15] Grossheim A.A. Flora of the Caucasus. 2nd edition. 1939--1967: vol. 1. Baku: Azerbaijan Publishing House. FAN USSR, 1939, 404 p.; vol. 2. Baku: Publishing House of Azerbaijan. FAN USSR, 1940, 284 p.; vol. 3. Baku: Publishing House of Azerbaijan. FAN USSR, 1944, 322 p.; vol. 4. Moscow; Leningrad: Publishing House of the Academy of Sciences of the USSR, 1950, 314 p.; vol. 5. Moscow; Leningrad: Publishing House of the Academy of Sciences of the USSR, 1952, 456 p.; vol. 6. Moscow; Leningrad: Publishing House of the Academy of Sciences of the USSR, 1962, 424 p.; vol. 7. Moscow; Leningrad: Publishing House of the Academy of Sciences of the USSR, 1967, $894 \mathrm{p}$. 
[16] Cherepanov S.K. (1995). Vascular plants of Russia and adjacent states. St. Peterburg: World and Family-95, 990 p.

[17] Keller, B. (1910). On the effect of salts on the distribution of vegetation. Diary of the XII Congress of Russian naturalists and doctors in Moscow. Moscow, pp. 39--47.

[18] Samoilov, A.P. (1964). On the question of the role of halophytic vegetation in the conditions of Khakassia. Plant Indicators of Soils, Rocks and Ground Waters. Moscow, pp. 43--51.

[19] Vitman, P.A., Pozdnyakov, E.P. (1968). Dependence of vegetation cover on soil salinization of the sodic complex of the central forest-steppe of the Omsk region. Uch. zap Omsk State ped. Inst., Ex. 38, pp. 70--77.

[20] Shahs, A.A. (1956). Salt tolerance of plants. Moscow, 552 p.

[21] Gubanov, I.A., Krylova, I.L., Tikhonov, V.L. (1976). Wild useful plants of the USSR. Moscow: Thought, $360 \mathrm{p}$.

[22] N.V. Tsitsin, What makes wheat crossing with wheat grass. Moscow, 1937, $49 \mathrm{p}$.

[23] Tsitsin, N.V. (1965). Hybridization of plants. Moscow, 149 p.

[24] Nagayevsky, V.Ya. (1984). Halophytes of the North Caucasus as a source medicinal raw materials. proc. report I Republican conf. on medical botany. Kiev, p. 33.

[25] Nagayevsky, V.Ya. (1990). Solonchak vegetation of the Eastern Azov region-reserve fodder base for livestock. Materials scientific and practical. conf. "Actual problems of ecology and environmental protection of the Azov Sea and East Azov Sea region". Krasnodar, p. 88--91.

[26] Taisumov, M.A., Astamirova, M.A.-M. (2018). Forage Plants of Chchenia and Classification of Natural Forage Lands. Advances in Engineering Research, vol. 151, pp. 963--970. International Conference on Smart Solutions for Agriculture (AgroSMART 2018).

[27] Taysumov, M.A., Umarov, M.U., Abdurzakova, A.S., Astamirova, M.A.-M. (2017). Halophilic-xerophilous flora of deserts and semi-deserts of the Terek-Kuma lowland within the Chechen Republic. Proceedings of the XIX International Conference "The biological diversity of the Caucasus and southern Russia", pp. 300--303. Makhachkala.

[28] Taysumov, M.A., Abdurzakova, A.S., Magomadova, R.S., Astamirova, M.A.-M. (2014). Classification of halophytes of the Terek-Kuma lowland according to anatomical and physiological characteristics. Bulletin of the Academy of Sciences of the Czech Republic, no. 1(22), pp. 35--46.

[29] Taysumov, M.A., Abdurzakova, A.S., Astamirova, M.A.-M., Magomadov, R.S. (2013). Halophytes of the Terek-Kumsk lowland and their ecological analysis. Materials 
of All-Russian. scientific conference "Actual problems of Ecology and biodiversity conservation in Russia and adjacent countries of Vladikavkaz", pp. 96--105.

[30] Taysumov, M.A., Magomadova, R.S., Abdurzakova, A.S. (2013). Abstract of the flora of the Terek-Kuma lowland. Grozny, $129 \mathrm{p}$. 